\title{
Right-wing populism as a nationalist vision of legitimating collective choice: a supply- side perspective
}

Article

Accepted Version

Halikiopoulou, D. (2019) Right-wing populism as a nationalist vision of legitimating collective choice: a supply-side perspective. The International Spectator, 54 (2). pp. 35-49. ISSN 0393-2729 doi:

https://doi.org/10.1080/03932729.2019.1588544 Available at https://centaur.reading.ac.uk/82405/

It is advisable to refer to the publisher's version if you intend to cite from the work. See Guidance on citing.

To link to this article DOI: http://dx.doi.org/10.1080/03932729.2019.1588544

Publisher: Taylor \& Francis

All outputs in CentAUR are protected by Intellectual Property Rights law, including copyright law. Copyright and IPR is retained by the creators or other copyright holders. Terms and conditions for use of this material are defined in the End User Agreement.

www.reading.ac.uk/centaur 
Central Archive at the University of Reading

Reading's research outputs online 


\title{
Right-wing Populism as a Nationalist Vision of Legitimating Collective Choice: A Supply-Side Perspective
}

\author{
Daphne Halikiopoulou \\ University of Reading
}

\begin{abstract}
Right-wing populist parties have significantly increased their electoral support in recent years. This has also triggered an increase in scholarly interest in the topic. Most existing explanations focus on demand, putting forward different versions of a cultural grievance story underpinned by a common focus on immigration. Instead, in order to understand the rise of right-wing populism, the focus must also be on the supply-side and more specifically on the ways rightwing populists themselves attempt to make their message more appealing to broader sectors of the population. At the core of this argument is nationalism: the examples of the German AfD and the French FN show that the adoption of a predominantly civic nationalist rhetoric allows these parties to appear legitimate to a broad range of social groups with different backgrounds and preferences.
\end{abstract}

Keywords: right-wing populism; nationalism; immigration; AfD, FN

\section{Introduction}

There is a broad trend underpinning politics across Europe and the West towards limiting immigration. Since the 2014 European Parliament (EP) elections, and subsequent national elections in a range of European countries, parties pledging to control immigration and restore national sovereignty in the name of the 'people' have significantly increased their vote share, often doubling or tripling their support. The French National Front (Front National, (FN) (now Rassemblement National), the Dutch Freedom Party (Partij voor de Vrijheid, PVV), the Alternatives for Germany (Alternative für Deutschland, AfD), the Austrian Freedom Party (Freiheitliche Partei Österreichs, FPÖ) and the Italian Lega (formerly Lega Nord, LN, Northern League), all made headlines in 2017 and 2018, some entering parliament for the first time, and others joining governing coalitions. For example, following the 2017 Austrian election, the FPÖ gained access to office, forming a governing coalition with the centre-right People's Party (Österreichische Volkspartei, ÖVP). In addition, the March 2018 Italian elections returned a 13 percent vote share increase for Matteo Salvini's LN compared to 2013, subsequently resulting in the party joining a 'populist' coalition government (Garzia 2018). In Eastern Europe too, the authoritarian turn of countries such as Poland and Hungary is often justified in the name of popular sovereignty by the right-wing populist Law and Justice party (Prawo $i$ Sprawiedliwość, PiS) and Fidesz (Fidesz - Magyar Polgári Szövetség, Hungarian Civic Alliance), respectively. 
For many, this is part of a broader trend of the mainstreaming of far right ideas (Halikiopoulou 2018). Brexit in the UK is a notable example of such populism (Bonikowski et al. 2019; Freeden 2017). This refers both to the Vote Leave campaign, as well as the urgency with which those supporting Brexit have sought to implement it, often bypassing parliamentary checks and balances (Freeden 2017). Outside the European context, Jair Bolsonaro in Brazil and Donald Trump in the United States are also pertinent examples of right-wing populists in power (Mounk and Kyle 2018). Despite being outside Europe, these examples are often treated in academics works as comparable to the cases of European right-wing populism mentioned above (see e.g. Inglehart and Norris 2016; Mounk and Kyle 2018). This implies that right-wing populism need not necessarily be confined to Europe despite the fact that opposition to the EU is often cited as a key component of right-wing populism. While euroscepticism can be an important characteristic of a right-wing populist party, it is not a necessary condition for a right-wing populist party to be Eurosceptic, and indeed there are Eurosceptic parties that are not right-wing populist and vice versa (see e.g. the classification offered in Rooduijn et al. 2019). Examples from around the world, extending outside the European context, reveal the breadth and persistence of this phenomenon.

The obvious question concerning scholars, political analysts and policymakers, is what explains this phenomenon. Most existing explanations focus on demand. Such explanations put forward different versions of a cultural grievance story, all underpinned by a common focus on immigration (See e.g. Ivarflaten 2008; Lucassen and Lubbers 2012; Inglehart and Norris 2016; Golder 2016; Stockemer 2015). This story centres on the emergence of a new transnational cleavage (Hooghe and Marks 2017; Inglehart and Norris 2016). The core idea is that, as cultural concerns overtake economic concerns in importance among voters, and immigration becomes the most salient issue, parties that cater to this issue become prominent players in the electoral arena. Some theories focus on noncultural grievances relating to immigration, including for example economic grievances or ones that have to do with a decline in the quality of public services, rising crime and weakening of societal cohesion (Lucassen and Lubbers 2012; Sniderman et al. 2004; Rydgren 2008). There is also an emerging scholarship extending beyond the immigration issue as a driver of far right party support, placing its focus instead on protest voting and government dissatisfaction, trust, poor governance, the loss of social status and the welfare state (Argeberg 2017; Halikiopoulou and Vasilopoulou 2018; Gidron and Hall 2017; Halikiopoulou and Vlandas 2016; Afonso and Renwald 2017).

While, therefore, there is disagreement in this literature about the factors that trigger opposition to immigration, that is, the extent to which the economy still matters in the context of the new transnational cleavage and the extent to which non-immigration related grievances matter, the common denominator is an implicit -- or at times more explicit -- assumption that demand drives supply. In other words, that the rise of populism is very much a demand-driven phenomenon in which popular discontent, exacerbated by external triggers such as immigration and globalisation, translates into voting for such parties. The supply-side, on the other hand, is largely overlooked, especially in the more 
recent literature that focuses on the rise of populism since 2017 and 2018 . While there is a rich supply-side scholarship assessing political opportunity structures (POS) and discursive opportunity (DOS) dynamics in the study of the far right (E.g. Rooduijn 2014; Koopmans and Statham 1999; Carter 2002; Bonikowski and Gidron 2015; Hawkins 2009; Manucci and Weber 2017; Rooduijn and Pauwels 2011; Jagers and Walgrave 2007; Ellinas 2011; Halikiopoulou et al. 2013), increasingly this is being taken over by the prolific systematic research on the demand-side.

This article offers instead a supply-side perspective. It argues that in order to understand the rise of right-wing populism we must also focus on the supplyside and, more specifically, on the ways right-wing populists themselves are attempting to make their message more appealing to broader sectors of the population. At the core of this argument is nationalism: drawing on Halikiopoulou et al. (2013), the article suggests that the adoption of a predominantly civic nationalist rhetoric allows these parties and groups to appear legitimate to a broad range of social groups with different backgrounds and preferences. This civic nationalist message constitutes a shift away from organic justifications of culture. By adopting it, right-wing populists refrain from using ascriptive criteria of exclusion, instead defining as outsiders those who do not share 'our' values of democracy and tolerance. This allows them to justify the exclusion of a variety of population groups on the basis that they are a purported threat to society's value consensus, and hence stability and prosperity.

It is important to clarify here that this is not a normative argument. Civic nationalism is not the equivalent of 'good' nationalism; nor does the argument suggest that right-wing populist parties are not actually racist. Such a claim would require empirical analysis which is outside the scope of this article. Rather, the argument put forward here is an analytical argument about the ways in which right-wing populist parties present themselves through their official discourse materials. In other words, civic nationalism is understood here as a communication tool right-wing populist parties utilise in order to appeal to broader sections of the population. Its adoption does not shield from extremism. On the contrary, it potentially makes these parties more dangerous by allowing them to permeate mainstream ground and, in many ways, drive party competition.

The article proceeds as follows. It commences with an overview of populism more broadly, briefly examining patterns of populism in Europe, and the (re) emergence of right-wing populism in particular. Second it overviews the extant literature that examines the demand-side of right-wing populism. Third, it discusses its argument, justifying the importance of supply. Fourth, it proceeds to illustrate the argument empirically by discussing the ways in which civic nationalism is used in the electoral campaigns of a number of right-wing populist parties. The article concludes with some recommendations for future research.

\section{Populism}


Populism is not a new concept (Abromeit et al. 2015). Indeed, the study of populism has a long history, not restricted to Europe and North America (Brubaker 2017b,14). It has been used in academic works for decades, in various contributions defining the concept (see e.g. Canovan 1981; Ionescu and Gellner 1969), and describing a range of movements and political outcomes, some much different to those that dominate the headlines today. These include, but are not confined to Russian 19th century populists (Berlin et al. 1968), classic midtwentieth century Latin American populisms (Weyland 2001; Brubaker 2017b); the emergence of populist parties in Europe during the 1980s and 1980 (90s ?), for example the Greek PASOK (Panellinio Sosialistiko Kinima, PanHellenic Socialist Movement) (Pappas 2013a) and religious populists (Stavrakakis 2002; Halikiopoulou 2011). While this literature discusses different populist contexts, many of the underlying themes remain the same, for example the idea that populism "occurs in societies that stand on the edge of modernization" (Berlin et al. 1968, p10) and that it "stresses 'the 'internal' values of the chosen group as against the 'external' values of the enlightened cosmopolitanism" (Berlin et al. $1968,3)$. The relationship between populism and nationalism is not new either as much of the literature expects the two to go hand in hand especially in rightwing populist agendas (Bonikowski 2017; Bonikowski et al. 2019; Mudde 2004; Berlin et al. 1968; Betz 1994).

The revival of the term 'populism' in the past few of years has taken place within the context of an emerging literature that focuses specifically on contemporary niche parties from the far right or far left end of the political spectrum. These parties claim to bring power back to the people, an entity juxtaposed against some corrupt elite (Mudde 2007). This literature is dominated by a debate as to whether populism in an ideology, communication style or strategy (Gidron and Bonikowski 2013). Going beyond this debate, this article follows Riker's (1982) definition of populism as a vision of legitimating collective choice in democracies. This definition captures the essence of populism: in a nutshell, that it is antithetical to liberal democracy and the institutions that secure its procedures. In this sense, populism is conducive to authoritarianism: while liberal democracy emphasizes pluralism, checks and balances and the rights of the individual to be protected from the state, populism does the opposite: it is pitted against the individual, favours the collective, and sees the 'people' as 'one' indivisible entity (Freeden 2017), failing to appreciate that society in fact consists of different social groups with different preferences that often clash and need to be reconciled.

The term populism is in many ways problematic (see e.g. Brubaker 2017b). As noted above, populism is chameleon-like, taking many forms, including both right-wing and left-wing (Bonikowski et al 2019). The main contention with regard to using the term itself is whether this chameleon-like character makes it just an empty buzzword; in other words whether it is too broad, nebulous and all-encompassing to be useful analytically (Bonikowski et al. 2019; Brubaker 2017b; Halikiopoulou 2018; Berlin et al. 1968). This theoretical shortcoming entails that a populist party or group may be difficult to identify empirically. The defining criteria might be too broad if we adopt the thin - or minimal (Mudde and Rovira Kaltwasser 2012) definition (that is, merely the pure people vs. the 
corrupt elites dimension), or overlapping too much with other categories such as radical right or radical left, extremism, nationalism, etc, if we adopt the thick definition which adds dimensions such as insiders vs. outsiders (Bonikowski et al. 2019; Brubaker 2017b).

This stresses the need for a carefully crafted definition that identifies clearly identifiable criteria of populism and its different versions. We must not suffer from a 'Cinderella complex', warns Isaah Berlin, during a conference on populism held at the London School of Economics in 1967. That is, we must not assume that "somewhere there exists a shoe -- the word populism -- for which there is a perfect fit" (Berlin et al. 1968: 6) and set out in a perpetual quest to find that shoe. At the same time,

we must not be tempted in the other direction, which some have taken, to suppose that the word 'populism' is simply a homonym; that there are movements in America, in Russia, in the Balkans and in Africa, that they are all called populism owing to confusions in human heads, but that they have too little in common (Berlin et al. 1968, 7).

How can we do this in order to operationalize the term in a way to facilitate solid empirical research on the topic? Drawing on Riker (1982) and Brubaker (2017b), I suggest three key characteristics that allow us to spot a populist individual, party or group. First, populism emphasizes the role of the collective. At the core of populism lies the concept of popular will, which is considered morally superior (Riker 1982) and indivisible (Freeden 2017). Its implementation into policy is the only legitimate mechanism for formalizing social choice. Precisely because only decisions made bottom-up by the people are legitimate, populism idealises the collective at the expense of the individual. This makes it more compatible with ideologies and movements that are collectivist: communism, fascism and statism. Second, by extension, populism is majoritarianist (Brubaker 2017b). Because it is based on the problematic equation of part of the people all of the people (Müller 2016), it effectively posits that the will of the majority is superior to the will of the minorities. This often translates into the marginalization of minority groups. Third, and also by extension, populism is anti-institutional (Brubaker 2017b): it questions constitutionalism, the rule of law and parliamentary scrutiny on the premise that "elite-level decisions, which involve liberal democratic institutional paths, lack legitimacy because they do not represent the popular will" (Bonikoswki et al. $2018,7)$. These three features make populism fundamentally and by definition contradictory to liberal democracy. Populism opposes both the individual rights and freedoms that underpin liberal democratic systems, as well as the institutions and processes that guarantee these liberties and make liberal democracies function.

\section{Patterns of populism in Europe}

Beyond these core features, populism may change its character depending on whether it stems from the right or the left of the political spectrum. We may identify different types of populism based on how populists from either end of 
the spectrum define 'the people'. Right-wing populism defines the people on the basis of an in-group/ out-group dimension. The people are the in-group, the only group that should be entitled access to the collective goods of the state. As such, right-wing populism focuses on limiting immigration. Left-wing populism defines the people on the basis of a haves and have-nots dimension. The people are those who suffer from economic exploitation and Western imperialism (Brubaker 2017b; Bonikowski et al. 2019).

The above conceptualisation allows us to identify different patterns of populism in Europe. Broadly speaking, these depend on the interaction between the populist axis and the cleavage that is salient -- or most important -- in each set of cases. In southern Europe, the dominant pattern is that of left-wing populism, manifested for example by the rise of Podemos (We can) in Spain and Syriza (Synaspismós Rizospastikís Aristerás/Coalition of the Radical Left) in Greece. This is very much the product of the resilience of a materialist cleavage in these societies, within the context of severe crisis dynamics. As debtor countries, southern European countries have experienced the severity of the Euro crisis, entailing that parties competing in these electoral arenas draw heavily on material factors in their electoral campaigns. In eastern Europe, the dominant pattern is that of populist authoritarianism; this can in many ways be understood as the product of historical conjectures, political culture and the communist experience (Pirro 2014). Finally in northwestern Europe the dominant pattern is that of post-materialist right-wing populism, characterised by the electoral success of parties that emphasise a cultural backlash in their populist narratives. This does not mean that materialist considerations are irrelevant, but rather that politics is shaped by two dimensions of contestation (Halikiopoulou and Vlandas 2019 forthcoming).

As noted above, right-wing populism combines the people vs. elites axis with a nationalist axis. The result is a rhetoric that claims to restore national sovereignty in the name of the people; in order to do so outsiders must be excluded from the national pact and the provision of its collective goods. Examples across western Europe, as noted above, are numerous parties that have increased their electoral fortunes by claiming that immigrants erode the national pact between people and state. Examples include the FN, which progressed to the second round of the 2017 French presidential election for the first time since 2002, receiving 33.9 per cent of the votes; the Dutch PVV, which increased its representation during the 2017 Dutch parliament elections by 5 seats, receiving 13.1 per cent of the votes; the Austrian FPÖ, which received 26 per cent of the votes and subsequently joined a governing coalition; the German AfD which entered parliament for the first time after receiving 12.6 per cent of the votes during the 2017 German parliament elections; the LN, which came in third place in the March 2018 Italian elections with 17.69 per cent of the votes, subsequently forming a populist coalition government with the Five Star Movement (Movimento 5 Stelle, M5S); and the Sweden Democrats (Sverigedemokraterna, SD) which also made electoral gains receiving 17.6 per cent of the votes during the September 2018 Swedish elections. 
This article focuses specifically on right-wing populism, proceeding with a brief overview of demand-side explanations, and outlining its own argument that focuses on supply.

\section{Why? The demand-side dimension of right-wing populism}

The increase in the share of votes for right-wing populist parties and groups has been accompanied by a sharp rise in the number of academic works seeking to shed light on this phenomenon (see e.g. Mudde and Rovira Kaltwasser 2018). It is widely accepted in this literature that, whatever the source of their discontent, disaffected voters often opt for parties that may be broadly described as democratic challengers (Bell 1964; Lipset 1960; Arendt 1961). Often, societal crises are seen as the triggers for this discontent. Democratic challengers gain momentum precisely because discontented voters see other alternatives as unable to alleviate their political, social, and/or economic misery (Arendt 1951). This is why the rise of populism is expected to occur in societies, which are, for example, on the brink of modernisation (Berlin et al.1968). In other words, there is one common underlying assumption that underpins this literature: demand drives supply. Despite the obvious differences between the various types of populism previously described, these are often understood as symptoms of the same malaise: the inability of mainstream politics to address mounting popular discontent.

Most explanations focus on the roots of this discontent. These range from economic insecurity (Halikiopoulou and Vlandas 2016; Swank and Betz 2003), to the loss of social status (Gidron and Hall 2017) and a potential cultural backlash (Inglehart and Norris 2016) triggered by globalisation, immigration and the perceived costs of EU membership for voters. The emerging consensus is precisely on this latter point: that is, that demand for right-wing populism is culture- or value- driven. In sum, voters' materialist concerns are being superseded by value-driven grievances within the context of an emerging transnational cleavage that divides those in favour from those against globalisation, multi-culturalism and cosmopolitanism (Hooghe and Marks 2017). Support for right-wing populism comes from the losers of this process who seek to maintain their national way of life against cosmopolitans and outsiders. The increased salience of immigration among voters, usually at the individual level, is often presented as evidence in support for this thesis (Ivarsflaten 2008; Lucassen and Lubbers 2012; Golder 2016).

Surprisingly, less attention is paid to supply, that is, what these parties are themselves doing in order to attract electoral support. This is particularly true in terms of the new and emerging literature on the topic in the past few years. Supply, is important because, while demand is indeed a driver of voter choice, there is still much it cannot explain. First, because it is often a constant: while multi-faceted discontent exists in all societies, not all societies have successful right-wing populist parties. Countries such as Spain until 2018, ${ }^{1}$ Portugal,

1 While right-wing populist party Vox won seats in Andalusia in 2018, this is relatively late compared to right-wing populism elsewhere in Europe, especially 
Ireland and Canada all have discontent voters in many ways failed by the political establishment, but this discontent is not translated into support for right-wing populism. Second, at the aggregate level, demand-side variables, such as immigration and unemployment, do not correlate with right-wing populist party support (Stockemer 2015; Halikiopoulou and Vlandas 2016; Halikiopoulou and Vasilopoulou 2018). Third, there are important variations within countries: what determines which right-wing populist party will be successful when more than one such parties compete within a domestic political arena? For example, in Germany it is the AfD rather than the NDP (Nationaldemokratische Partei, National Democractic Party) that is winning the votes; in Greece it is the Golden Dawn (GD, Laikós Sýndesmos - Chrysí Avgi) rather than LAOS (Laikós Orthódoxos Synagermós, Popular Orthodox Rally); and in Austria it is the FPÖ rather than the BZÖ ( Bündnis Zukunft Österreich, Alliance for the Future of Austria).

\section{A supply-side perspective: populism's nationalist vision of legitimating collective choice}

It could be argued that instead of simply responding to popular demand, parties are themselves also shaping it. Simply put, a better way of understanding these phenomena is by focusing on the ways in which parties change their rhetoric and programmatic agendas to capitalise on demand-side opportunities and entrench themselves in their respective party systems. They do so, this article argues, by putting forward a (civic) nationalist vision of democratic politics. As noted above, this is not a normative argument. This article does not make a value judgement about whether civic nationalism is a good nationalism, nor does it suggest that by adopting this narrative, right-wing populist parties are not actually racist. Rather, the article puts forward an argument about the ways in which right-wing populist parties communicate their messages, often disguising exclusionary agendas with value-based appeals in order to become more palatable to broader sections of the population.

As noted above, right-wing populism feeds off conflict lines, by dividing on two dimensions: the 'people versus the elites' and the 'in-group versus the outgroup'. Simply put, the former is the populist dimension and the latter is the nationalist dimension. The vision of democracy they put forward is one where the in-group is prioritised in terms of policy and provision of common goods. If, therefore, populism is a way of legitimating collective choice, right-wing populism is a way of legitimating the collective choice of the in-group. Its appeal, therefore, premised on the ability of draw on voters' multiple insecurities and to normalise exclusion, can be better understood through a nationalism framework.

In other words, the electoral success of right-wing populist parties and what accounts for their ability to broaden their appeal beyond their secure voting base, can be partly explained by the type of nationalism they use in their rhetoric

given the crisis context that Spain has faced. There is substantial literature trying to explain why there has been no far right party in Spain and why the country has not followed broader European trends (see e.g. Alonso and Kaltwasser 2015; Ellwood 1995; Halikiopoulou and Vasilopoulou 2018). 
and programmatic agendas, i.e. the ways in which they define the in-group and justify exclusion of the out-group (see also Miller-Idris (2019) on the use of nationalist frames). Specifically this article argues that the increased relevance of right-wing populist parties is linked to the manner in which they employ civic nationalism in their rhetoric and programmatic agendas. This is because the adoption of this type of nationalism allows parties with exclusionary agendas to appear legitimate to a broad section of the population.

At the core of this type of civic nationalist rhetoric are right-wing populist party positions on immigration and justifications for them. Right-wing populist parties traditionally have ownership of the immigration issue (See e.g. Ivarsflaten 2008; Lucassen and Lubbers 2012; Van Spagne 2010). They maintain that those who are not members of the in-group should be excluded from the national polity and be denied access to the collective goods of the state. The question then inevitably becomes, who is a member of the polity? And most importantly, what are the criteria used to determine this? The questions of whether someone is a member of the polity, and when one becomes a member, are outside the scope of this article. Rather, what is of concern here is which groups right-wing populist parties define as outsiders and why. Often, right-wing populist parties include native-born residents or citizens in their categorisation of 'immigrant groups' (Asari et al. 2008). The civic nationalist narrative is important in explaining the ways in which they justify this: increasingly less in terms of descent, as they seek to distance themselves from race-based framing grounded in origins, and more in terms of value-based arguments that emphasise democratic principles, presenting as outsiders those who not adhere to them.

This argument draws on the work of Halikiopoulou et al. (2013), which has argued this point both theoretically and empirically, focusing on European far right parties. This work has shown that, in Europe, the far right parties that enjoy relative success in mainstream electoral politics, such as the Swiss People's Party (Schweizerische Volkspartei, SVP), the United Kingdom Independence Party (UKIP) and the FN (now Rassemblement National), tend to be the ones best able to distance themselves from primordial and ascriptive elements of national identity such as race, creed, blood and kinship, and instead adopt civic values including democracy, citizenship and respect for the rule of law. This argument fits within a broader supply-side literature that focuses on far right normalization strategies (e.g. Golder 2003; Mayer 2015), arguing that the most successful far right parties in Europe are those that have abandoned connections with fascism, favouring instead a new ideological basis. It is important to note here that this discursive choice is neither static nor linear: parties may again change the way in which they use nationalism in their rhetoric and programmatic agendas depending on changes in demand, party system dynamics and new political opportunities. UKIP is an example of a party shifting from a predominantly civic type of nationalism to a more ethnic one after the Brexit referendum for reasons mainly specific to the British context. Despite such individual cases, the broader European trend is towards the adoption of normalization strategies that employ predominantly civic nationalist narratives. 
The 'civic nationalist normalization' strategy (Halikiopoulou and Vlandas 2019) is underpinned by the portrayal of cultural issues as value-driven and ideological, as opposed to biological. While nationalism -- understood as the attainment and maintenance of the autonomy, unity and identity of the nation (Breuilly 2005) -- is key to the programmatic agendas of all right-wing populist parties, it is usually assumed in the literature that far right parties are nativist (Mudde 2007), adopting ethnic nationalist agendas (Hainsworth 2008). The latter, refers to the type of nationalism that justifies exclusion on ascriptive criteria of belonging, such as blood, creed and common descent. Right-wing populist parties, however, are increasingly adopting civic nationalist narratives, focusing instead on adherence to political values and institutions as the key criteria of defining the in-group and out-group. Such narratives justify exclusion on the basis of a purported inability, or refusal, of certain population groups to adhere to 'our' liberal democratic values because their values are inherently antithetical (Halikiopoulou et al. 2013). In other words, they invoke a form of a 'clash of civilizations' thesis, framing identity in "civilisationist" terms (Brubaker 2017a; Betz and Habersack 2019), which also explains their staunch anti-Islamic discourse.

In sum, the key to this supply-side perspective is nationalism. In this sense, it has greater explanatory value than populism, which is insufficient in itself in explaining the rise of right-wing variants, as it is more generic and may be used, as mentioned above, to describe a broad range of liberal democracy's challengers. While both populism and nationalism emphasize conflict lines, focus on the collective, and put forward a vision of an ideal society, they are indeed conceptually different (Bonikowski et al. 2019). It is the chameleon-like character of nationalism (Hall 2011; Zimmer 2003) and its flexible quality as a thin ideology (Freeden 1998) that allows right-wing populists to tailor their narratives accordingly.

The article proceeds to sketch briefly the civic nationalist narratives of two European right-wing populist parties: the German AfD and the French FN. While these parties differ in many ways relating to their origins and historical development, what they share is a common anti-Islamic narrative, which exemplifies the ways in which they use a civic nationalist discourse to frame their message. The overarching commonality is an emphasis not on Muslims per se, but rather on Islamism as an ideology -- a value system, which they identify as antithetical to that of liberal democracy. This also helps them resolve tensions between defining the out-group through a race-base framing -- for example many perpetrators of terrorist attacks in France were actually native-born second or third generation French citizens -- and distancing themselves from explicitly racist arguments. They do so through the adoption of an ideological rather than biological justification of exclusion, which presents Islam as a breach of the Western liberal democratic consensus. These people are defined as foreign not because of their ethnic descent, but for voluntaristic reasons: because they do not adhere to Western liberal democratic values.

It is important to note here that measuring the uptake and resonance of this message is outside the scope of this article. This article does not make 
deterministic claims about supply, nor does it suggest that demand is irrelevant to the understanding of right-wing populist party support. The aim of the next few lines is to focus on two examples that illustrate the ways in which supply also matters in our understanding of this phenomenon. Future research could focus more on the interplay between demand- and supply-side dynamics, testing how and to what extent the civic nationalist message resonates among different social groups with different backgrounds and preferences.

\section{Europe's civic right-wing populists}

\section{The AfD}

The election of the AfD in the German Bundestag in 2017 in many ways marked the end of German exceptionalism with regard to right-wing populism. While other parties on the far right end of the political spectrum, such as the NDP, competed in elections previously, they have tended to remain marginalized in the German political system. Why? This case is a good example of the limitations of demand- side explanations. For example, while the cultural backlash thesis stresses the importance of anti-Islamic sentiments as drivers of support, in fact in 2017 the AfD performed particularly well in the east of Germany which has a very small Muslim population compared to the west (Betz and Habersack 2019). Thus anti-Islamic sentiments alone cannot explain the AfD's disproportionate success in the east. Nor can economic anxiety: individual level analyses of AfD support suggest that the party's voters do not fit the typical blue collar/ economically deprived far right voter profile (Betz and Habersack 2019). The limits of demand point to the importance of supply-side dynamics.

The AfD fits within the right-wing populist party category (Betz and Habersack 2019). The party claims to speak in the name of the people, and equates these people with a culturally defined in-group. It attributes blame to immigrants, and particularly Muslims, for a range of social problems thus appealing to voters' multiple insecurities. What is distinct about the AfD in comparison to other German parties on the far right of the political spectrum is the way that it does this, through the use of a particular type of nationalist narrative that it employs in its programmatic agenda. Refraining from overt references to racism (Arzheimer 2015), the party centres its nationalism in cultural threats posed by those whose values are antithetical to 'ours'.

This is evident in the ways in which the party communicated its message during the 2017 election campaign. In sum, this was centred on portraying Islam as a threat to German values. A series of AfD posters chose images symbolising the Western, and sometimes specifically German way of life, such as traditional dress, food, drink, and beachwear, juxtaposing them to what the party identifies as symbols of Islam such as the burka and the prohibition of certain foods and drink such as pork and alcohol (AfD 2017). The idea was to build on a series of fabricated divisions at the core of which is culture: freedom vs. restriction; progressive values vs. reactionary ones; and tolerance vs. intolerance. The civic nationalist message of this narrative is clear: by seeking to limit freedom, Islamic 
values not only erode the traditional German way of life, but are actually antithetical to the very essence of the liberal democratic vision of this society.

\section{The FN}

Unlike the AfD, the FN is a party with a much longer history. As such, it offers researchers a good platform for making cross-time comparisons. The party's performance across time has been characterised by ebbs and tides, revealing a cyclical pattern (Halikiopoulou 2018). Nonetheless, its electoral performance was particularly strong during the 2017 French presidential elections. The party has progressed to the second round of the French presidential elections twice: in 2002 and in 2017 . The 33.9 per cent it received in the second round of the latter is its highest percentage. This increase in the party's electoral support has also coincided with its ability to broaden its electoral base in recent years, gaining votes from across the political spectrum, including from groups less likely to vote for the far right, such as women (Mayer 2013).

The breadth of the FN's electoral appeal has coincided with the party's programmatic shift from predominantly ethnic to predominantly civic nationalism. This shift has been most evident in the transition of the party's leadership from Jean-Marie Le Pen to Marine Le Pen. During Jean-Marie Le Pen's leadership, the préférence nationale -- the party's key nationalist proposition that in France the French must come first -- was pursued through an "indirect racist discourse" (Hainsworth 2008). The pursuit of a de-demonization strategy by Marine Le Pen (Ivaldi 2015) has entailed a shift to priorité nationale, in an attempt to normalise the party, distance it from fascism and right-wing extremism, and thus extend its electoral appeal (Alduy and Wahnich 2015). Similarly to the discourse of the AfD, the FN also focuses on Islam in its attempt to place the immigration issue within a framework of a broader value conflict.

The party's position on terrorism illustrates this point well. Terrorism is an issue that has become increasingly salient across Europe in recent years, and particularly in France, which has experienced a series of attacks on its soil. The FN has been particularly active in its attempt to capitalise on voters' concerns with regards to terrorism, by linking the issue with immigration on its programmatic agenda. It has done so by employing a civic nationalist narrative that places terrorism within a broader framework of a value conflict, linking it to immigration and national security. For example, in the aftermath of certain attacks, the party repeatedly labelled terrorists as the "enemies of liberty" and described the "Islamist danger" as a "consequence of massive immigration" (Front National 2015). Through this type of rhetoric, the FN avoids racialized, descent-based exclusionary rhetoric, instead portraying terrorism as a breach of the French liberal democratic consensus (Hutchins and Halikiopoulou 2019).

\section{Conclusion}

This article has suggested that in order to understand the electoral success of right-wing populist parties across Europe, we need to extend our analyses beyond demand-side explanations, and also take into account the importance of 
supply. More specifically, the article has argued that instead of just responding to popular demand, parties are themselves shaping it. They are doing so through by using a narrative that merges populism and civic nationalism. The most electorally successful far-right parties in Europe are those that are able to merge their populist narrative -- that is, their claim to speak on behalf of the people and restore national sovereignty -- with a nationalist narrative, that is, an attempt to define this people as an in-group that solely deserves access to the collective goods of the state. If, in other words, as per Riker (1982), populism is a way of legitimating collective choice, right-wing populism is a way of legitimating this choice by putting forward a nationalist vision of (pseudo) democratic politics. For the most successful right-wing populist parties, this nationalist vision is a civic one: it defines the out-group in ideological rather than biological terms, making exclusion more easily justifiable.

To illustrate the point empirically, the article has focused on two parties: the German AfD and the French FN. In the case of the former, the idea is to show how a right-wing populist party may be successful within the German context; in the case of the latter to illustrate how the party has both broadened and increased its electoral appeal after it changed its supply. In both cases, the common underlying theme is the adoption of a civic form of nationalism, which has allowed the parties to attract votes from across the political spectrum.

Why is this important? In short, the contribution of this article is twofold. First, the civic nationalism theoretical perspective sheds light on how other parties respond. While extreme right or far right parties tended to be ostracised and isolated in the past, right-wing populist parties have been able to permeate the mainstream. The ability to present immigration as a value problem and thus to distance themselves from racism and right-wing extremism, makes these parties more acceptable to a broader range of voter groups. The problem is not only the electoral gains these parties are making, but also the increasing consensus that mainstream parties should respond by imitating them, i.e. adopting similar policy positions on certain issues, for example immigration. The adoption of the populism label further normalises what is essentially a far right discourse. In short, civic nationalism does not shield from extremism; it makes societies more vulnerable to extremism by disguising it.

Second, this perspective highlights a range of potential policy solutions that extend beyond the 'cultural backlash' conventional wisdom. Simply put, the demand-side distinction between culture and economy is in many ways a false dichotomy. Both are part of the solidarity pact between states and citizens, that is, the social contract (Halikiopoulou and Vasilopoulou 2018). As such, both are equally important to voters. Populist right-wing parties are increasing their electoral fortunes because, by proposing (civic) nationalist solutions to a variety of socio-economic problems, they are appealing to a broad range of voters with different insecurities. To compete with these parties, other parties must address these underlying insecurities, which go well beyond immigration. It entails a focus on the losers of the social contract and the policies that compensate them. 
Notes on contributor

Daphne Halikiopoulou is Associate Professor in Comparative Politics at the University of Reading, Reading, UK.

\section{References}

Abromeit, J., Chesterton, B. M., Marotta, G., and Norman, Y., eds. 2015. Transformations of populism in Europe and the Americas: history and recent tendencies. London: Bloomsbury Academic.

Afonso, A., and Rennwald, L. 2017. Social class and the changing welfare state agenda of populist radical right parties in Europe. In P. Manow and B. Palier, eds. Electoral Realignments and Welfare State Transformations in Europe. Oxford: Oxford University Press.

Afonso, A., and Papadopoulos, Y. 2015. How the populist radical right transformed swiss welfare politics: from compromises to polarization. Swiss Political Science Review. https://doi.org/10.1111/spsr.12182

Alternative für Deutschland (AfD). 2017. https://www.afd.de

Alduy, C., and Wahnich, S. 2015. Marine Le Pen prise aux mots: Décrytpage du nouveau discours frontiste. Paris: Seuil.

Alonso, S., and Kaltwasser, S.R. 2015. Spain: No Country for the Populist Radical Right? South European Society and Politics 20 (1): 21-45.

Arendt, H. 1951. The origins of totalitarianism. Cleveland: Meridian Books

Arzheimer, K. 2009. Contextual Factors and the Extreme Right Vote in Western Europe, 1980- 2002. American Journal of Political Science 53 (2): 259-75.

Arzheimer, K. 2015. The AfD: Finally a Successful Right-Wing Populist Eurosceptic Party for Germany? West European Politics 38 (3): 535- 556.

Asari, E.M., Halikiopoulou, D., and Mock, S. 2008. British National Identity and the Dilemmas of Multiculturalism. Nationalism and Ethnic Politics 14 (1): 1-28.

Bell, D. 1964. The Dispossessed. In D. Bell, ed. The Radical Right: 1-45. Garden City, NY: Anchor.

Berlin, I. 1968. To Define Populism. Government and Opposition 3 (2): 137-79.

Betz, H.G. 1994. Radical Right-Wing Populism in Western Europe. New York: Palgrave Macmillan.

Betz, H.G., and Habersack, F. 2019 forthcoming. Regional Nativism in East Germany: The Case of the AfD. In R. Heinisch, E. Massetti and O. Mazzoleni, eds. 
The People and the Nation: Populism and Ethno-Territorial Politics in Europe. London: Routledge.

Bonikowski, B. 2017. Ethno-Nationalist Populism and the Mobilization of Collective Resentment. The British Journal of Sociology 68 (S1): 181-213.

Bonikowski, B., Halikiopoulou, D., Kaufmann, E., and Rooduijn, M. 2019. Nations and Nationalism Exchange: Nations and Nationalism 19 (1).

Breuilly, J. 2005. Dating the Nation: How Old is an Old Nation? In A. Ichijo, and G. Uzelac, eds. When is the Nation? Towards an Understanding of Theories of Nationalism: 15-39. London: Routledge.

Brubaker, R. 2017a. Between nationalism and civilizationalism: the European populist moment in comparative perspective. Ethnic and Racial Studies 40 (8): 1191-1226.

Brubaker, R. 2017b. Why Populism? Theory and Society 46 (5): 357.

Canovan, M. 1981. Populism. New York: Harcourt Brace Jovanovich.

Carter, E. 2002. Proportional Representation and the Fortunes of Right-wing Extremist Parties. West European Politics 25 (3): 125-46.

Ellinas, A. 2011. The media and the far right in Western Europe: Playing the Nationalist Card. Cambridge: Cambridge University Press.

Ellwood, S. 1995. The Extreme Right in Spain: A Dying Species? In L. Cheles, R. Ferguson and M. Vaughan, eds. The Extreme Right in Western and Eastern Europe. London: Longman.

Ennser, L. 2012. The homogeneity of West European party families: The radical right in comparative perspective. Party Politics 18 (March): 151.

Freeden, M. 1998. Is nationalism a distinct ideology? Political Studies 46 (4): 748-765.

Freeden, M. 2017. After the Brexit referendum: revisiting populism as an ideology. Journal of Political Ideologies 22 (1): 1-11.

Front National. 2015. Péril islamiste, Protégeons les Français. http://www.frontnational.com/2015/01/nouveau-tract-du-front-national-perilislamiste- protegeons-les-francais/

Garzia, D. 2018. The Italian election of 2018 and the first populist government of Western Europe. West European Politics 42 (3). DOI: $10.1080 / 01402382.2018 .1535381$ 
Gidron, N., and Bonikowski, B. 2013. Varieties of populism: literature review and research agenda. Weatherhead Working Paper Series No. 13-0004. Cleveland, OH: Case Western Reserve University, Weatherhead School of Management.

Gidron, N. and P. Hall. 2017. The politics of social status: Economic and cultural roots of the populist right. The British Journal of Sociology 68 (S1): 57-84.

Golder, M. 2003. Explaining Variation in the Success of Extreme Right Parties in Western Europe. Comparative Political Studies 6 (4). DOI:

10.1177/0010414003251176

Golder, M. 2016. Far right parties in Europe. Annual Review of Political Science 19 (1): 477-97.

Hainsworth, P. 2008. The extreme right in Western Europe. Abingdon: Routledge.

Halikiopoulou, D. 2011. Patterns of Secularisation: Church, State and Nation in Greece and the Republic of Ireland. Farnham: Ashgate. ISBN: 978-1-4094-0345

Halikiopoulou, D. 2018. A Right-wing Populist Momentum? A Review of 2017 Elections across Europe. Journal of Common Market Studies 19 (3). https://doi.org/10.1111/jcms.12769.

Halikiopoulou, D. , Nanou, K. and Vasilopoulou, S. 2012. The paradox of nationalism: The common denominator of radical right and radical left euroscepticism. European Journal of Political Research 51: 504-539. doi:10.1111/j.1475-6765.2011.02050.x

Halikiopoulou, D., Mock, S. and Vasilopoulou, S. 2013. The Civic Zeitgeist: Nationalism and Liberal Values in the European Radical Right. Nations and Nationalism 19 (1): 107-27.

Halikiopoulou, D., and Vasilopoulou, S. 2018. Breaching the Social Contract: Crises of Democratic Representation and Patterns of Extreme Right Party Support. Government and Opposition 53 (1): 26-50. doi:10.1017/gov.2015.43

Halikiopoulou, D. and Vlandas, T. 2016. Risks, Costs and Labour Markets: Explaining Cross-National Patterns of Far-Right Party Success in European Parliament Elections. Journal of Common Market Studies 54 (3): 636-55.

Hall, J. 2011. Nationalism might change its character, again. In D. Halikiopoulou and S. Vasilopoulou, eds. Nationalism and globalisation: Conflicting or complementary? London: Routledge.

Hooghe, L., and Marks, G. 2017. Cleavage theory meets Europe's crises: Lipset, Rokkan, and the transnational cleavage. Journal of European Public Policy 25 (1). doi: 10.1080/13501763.2017.1310279. 
Hutchins, R., and Halikiopoulou, D. 2019 forthcoming. Enemies of liberty? Nationalism, Immigration and the framing of terrorism in the agenda of the Front National. Nations and Nationalism (forthcoming)

Inglehart, R., and Norris, P. 2016. Trump, Brexit, and the Rise of Populism: Economic Have-Nots and Cultural Backlash. Harvard Kennedy School Faculty Research Working Paper Series No RWP16-026. Cambridge MA: Harvard University.

Ionescu, G., and E. Gellner. 1969. Populism: Its Meanings and National Characteristics. New York: Macmillan

Ivaldi, G. 2015. Towards the median economic crisis voter? The new leftist economic agenda of the Front National in France. French Politics 13 (4): 346-369.

Ivarsflaten, E. 2008. What unites right-wing populists in Western Europe? Reexamining grievance mobilization models in seven successful cases. Comparative Political Studies 41 (1): 3- 23.

Koopmans, R., and Statham, P. 1999. Ethnic and civic conceptions of nationhood and the differential success of the extreme right in Germany and Italy. In M. Giugni, D. McAdam and C. Tilly, eds. How Social Movements Matter: 225-51. Minneapolis, MN: University of Minnesota Press.

Lipset, S.M. 1960. Political Man: The Social Bases of Politics. New York: Doubleday.

Lucassen, G., and Lubbers, M. 2012. Who Fears What? Explaining Far-Right-Wing Preference in Europe by Distinguishing Perceived Cultural and Economic Ethnic Threats. Comparative Political Studies 45 (5): 547-574.

Mayer, N. 2015. The closing of the radical right gender gap in France? French Politics 13 (4): 391-414.

Miller-Idris, C. 2019. The Global Dimensions of Populist Nationalism, International Spectator

Mounk, Y., and Kyle, J. 2018. What populists do to democracy. The Atlantic. https://www.theatlantic.com/ideas/archive/2018/12/hard-data-populismbolsonarotrump/578878/?fbclid=IwAR0eI8rm8wumarlpAsZHItdUskOGbH0djnBpxlruIqr KK5wq8kFWh005cRU\&utm_campaign=theatlantic\&utm_content $=5 \mathrm{c} 2 \mathrm{~b} 08 \mathrm{f} 23 \mathrm{ed} 3 \mathrm{f} 00001 \mathrm{f57c} 2 \mathrm{~d} \_t \mathrm{ta} \& u t \mathrm{~m} \_$medium $=$social $\& u t$ m_source $=$ facebook

Mudde, C. 2004. The Populist Zeitgeist. Government and Opposition 39 (4): 542563.

Mudde, C. 2007. Populist radical right parties in Europe. Cambridge: Cambridge 
University Press.

Mudde, C., and Rovira Kaltwasser, C. 2018. Studying Populism in Comparative Perspective: Reflections on the Contemporary and Future Research Agenda. Comparative Political Studies 51 (13) doi.org/10.1177\%2F0010414018789490

Müller, J. -W. 2016. What is populism? Philadelphia: University of Pennsylvania Press.

Pappas, T. 2013a. Why Greece Failed. Journal of Democracy 24 (2): 31-45.

Pappas, T. 2013b. Populist Democracies: Post-Authoritarian Greece and PostCommunist Hungary. Government and Opposition, forthcoming.

Pappas, T.S. 2016. The Spectre Haunting Europe: Distinguishing Liberal Democracy's Challengers. Journal of Democracy 27 (4): 22-36.

Pirro, A. L. P. 2014. Populist radical right parties in Central and Eastern Europe: the different context and issues of the prophets of the patria. Government and Opposition 49 (4): 599-628.

Riker, W. 1982. Liberalism against Populism: A confrontation between the theory of democracy and the theory of social choice. Illinois: Waveland Press.

Rooduijn, M. 2017. What Unites the Voter Bases of Populist Parties? Comparing the Electorates of 15 Populist Parties. European Political Science Review 10 (3): $1-18$.

Rooduijn, M., Van Kessel, S., Froio, C., Pirro, A., De Lange, S., Halikiopoulou, D., Lewis, P., Mudde, C. and Taggart, P. 2019. The PopuList: An Overview of Populist, Far Right, Far Left and Eurosceptic Parties in Europe. http://www.popu-list.org.

Rydgren, J. 2008. Immigration sceptics, xenophobes or racists? Radical rightwing voting in six West European countries. European Journal of Political Research 47 (6): 737-765. doi:10.1111/j.1475-6765.2008.00784.x

Sniderman, P. M., Hagendoorn, L and Prior, M. 2004. Predisposing factors and situational triggers: Exclusionary reactions to immigrant minorities. American Political Science Review 98 (1): 35-49.

Stavrakakis, Y. 2002. Religion and Populism: Reflections on the Politicised Discourse of the Greek Church. London: The Hellenic Observatory, The European Institute, LSE.

Stockemer, D. 2016. Structural Data on Immigration or Immigration Perceptions? What Accounts for the Electoral Success of the Radical Right in Europe? Journal of Common Market Studies 54 (4): 999-1016.

doi: $10.1111 /$ jcms.12341. 
Stockemer, D., and Amengay, A. 2015. The voters of the FN under Jean-Marie Le Pen and Marine Le Pen: Continuity or change? French Politics 13 (4): 370-390. doi:10.1057/fp.2015.16

Van Spanje, J. 2010. Contagious parties: Anti-immigrant parties and their impact on other parties' immigration stances in contemporary Western Europe. Party Politics 16 (5): 563-586.

Weyland, K. 2001. Clarifying a Contested Concept: Populism in the Study of Latin American Politics. Comparative Politics 34 (1): 1-22.

Zimmer, 0. 2003. Boundary mechanisms and symbolic resources: Towards a process-oriented approach to national identity. Nations and Nationalism 9 (2): 173-193. 